\title{
ANALISIS KARAKTERISTIK SAMPAH DI BANTARAN SUNGAI GAJAH PUTIH SURAKARTA
}

\author{
Suryo Handoyo \\ Program Studi Teknik Sipil, Fakultas Teknik, Universitas Tunas Pembangunan Surakarta, Surakarta \\ suryo.handoyo@lecture.utp.ac.id \\ Yuliman Ziliwu \\ Program Studi Teknik Sipil, Fakultas Teknik, Universitas Tunas Pembangunan Surakarta, Surakarta \\ yuliman.ziliwu@lecture.utp.ac.id
}

\begin{abstract}
Abstrak
Pertambahan jumlah penduduk dan meningkatnya kepadatan hunian sepanjang tepian badan sungai Gajah Putih ditengarai menyebabkan bertambahnya volume sampah di DAS Gajah Putih. Ada beberapa aspek yang terkait sebagai penyebab pertambahan volume sampah tersebut.Untuk mengembalikan kondisi kebersihan sungai perlu diketahui karakteristik sampah yang mengendap di sepanjang sungai. Dengan diketahuinya karakteristik sampah maka dapat diperkirakan metoda untuk mengelola sampah tersebut. Pendataan jenis dan volume sampah dilakukan dengan mempetakan sebagian aliran sungai Gajah Putih dan dilakukan segmentasi daerah pengamatan. Hal tersebut dilakukan karena dari pengamatan secara kasar dapat diketahui pola keragaman dan sebaran sampah. Pendataan juga dilakukan guna mengetahui jenis dan volume sampah yang dihasilkan oleh penduduk sepanjang tepian aliran sungai. Dari hasil analisis dapat diketahui ketidaksesuaian antara karakteristik sampah di sungai Gajah Putih dengan sampah yang dihasilkan oleh penduduk sepanjang tepian aliran sungai tersebut. Hal tersebut menunjukkan bahwa sebagaian besar sumber timbulan sampah di aliran sungai Gajah Putih tidak berasal dari hunian tepi sungai tersebut.
\end{abstract}

Kata kunci: karakteristik sampah, pengelolaan, sumber sampah.

\begin{abstract}
The increase in population and the increase in occupancy density along the banks of the Gajah Putih river body are thought to have caused an increase in the volume of waste in the Gajah Putih watershed. There are several aspects related to the increase in the volume of waste. To restore the cleanliness of the river, it is necessary to know the characteristics of the garbage that settles along the river. By knowing the characteristics of the waste, the method for managing the waste can be estimated. Data collection on the type and volume of waste was carried out by mapping a portion of the Gajah Putih river flow and segmenting the observation area. This is done because from the rough observation it can be seen the pattern of diversity and distribution of waste. Data collection was also carried out to determine the type and volume of waste generated by residents along the riverbanks. From the results of the analysis, it can be seen that the mismatch between the characteristics of the garbage in the Gajah Putih river and the waste produced by residents along the banks of the river flow. This shows that most of the sources of waste generation in the White Elephant river flow do not come from the riverbanks.
\end{abstract}

Key words: waste characteristics, management, source of waste. 


\section{PENDAHULUAN}

Sungai Gajah Putih adalah sungai yang melintas di tepi Utara kota Surakarta. Pertumbuhan penduduk menyebabkan daerah tepi kota menjadi semakin padat hunian dan kepadatan pengguna akses jalan bertambah. Kondisi pada saat dilakukan survei di bantaran sungai tersebut terdapat tumpukan sampah. Tujuan dari penelitian ini adalah untuk mengetahui sumber dari timbulan sampah tersebut. Banyak faktor yang berperan sehingga sampah yang dihasilkan belum dapat dikelola secara baik. Bantaran sungai Gajah Putih adalah obyek yang diteliti terkait sampah yang menumpuk dilokasi tersebut.

Supaya tidak mengganggu lingkungan, kesehatan dan estetika perlu adanya pengelolaan, yaitu kegiatan yang sistematis, menyeluruh, dan berkesinambungan yang meliputi pengurangan dan penanganan sampah. Pengertian pengelolaan bukan hanya menyangkut aspek teknis, tetapi mencakup juga aspek non teknis, seperti bagaimana mengorganisir, bagaimana membiayai dan bagaimana melibatkan masyarakat penghasil limbah agar ikut berpartisipasi secara aktif atau pasif dalam aktivitas penanganan tersebut.

\section{LANDASAN TEORI}

Sampah adalah semua buangan yang dihasilkan oleh aktivitas manusia dan hewan yang berbentuk padat, lumpur (sludge), cair maupun gas yang dibuang karena tidak dibutuhkan atau tidak diinginkan lagi.

Definisi World Health Organization (WHO) sampah adalah sesuatu yang tidak digunakan, tidak dipakai, tidak disukai atau sesuatu yang dibuang yang berasal dari proses kegiatan manusia dan tidak terjadi dengan sendirinya (Chandra, 2006). UU No 18 tahun 2008 tentang Pengelolaan Sampah, menyebutkan sampah adalah sisa dari berbagai proses kegiatan setiap hari yang dilakukan manusia ataupun proses alam yang berbentuk padat atau semi padat berupa zat organik atau anorganik bersifat dapat terurai atau tidak dapat terurai yang dianggap sudah dapat bermanfaat dan dibuang ke lingkungan (Slamet, 2002). Sedangkan sampah adalah sisa bahan, limbah atau buangan yang bersifat padat, setengah padat termasuk juga cairan yang merupakan hasil sampingan dari aktifitas atau siklus kehidupan manusia, hewan maupun tumbuh-tumbuhan yang dianggap sudah tidak bermanfaat dan belum memiliki nilai ekonomis serta dibuang ke lingkungan.

Menurut Gelbert dkk. (1996) sampah dikelompokan berdasarkan asalnya, sampah padat dapat digolongkan sebagai:

1. Sampah Organik, terdiri dari bahan-bahan penyusun tumbuhan dan hewan yang diambil dari alam atau dihasilkan dari kegiatan pertanian,perikanan atau yang lain. Sampah ini dengan mudah diuraikan dalam proses alami. Sampah rumah tangga sebagian besar merupakan bahan organik. Termasuk sampah organik, misalnya sampah dari dapur, sisa tepung, sayuran, kulit buah, dan daun.

2. Sampah Anorganik, berasal dari sumber daya alam tak terbarui seperti mineral dan minyak 
bumi, atau dari proses industri. Beberapa dari bahan ini tidak terdapat di alam seperti plastik dan aluminium. Sebagian zat anorganik secara keseluruhan tidak dapat diuraikan oleh alam, sedang sebagian lainnya hanya dapat diuraikan dalam waktu yang sangat lama. Sampah jenis ini pada tingkat rumah tangga, misalnya berupa botol, botol

plastik, tas plastik, dan kaleng. Karakter sampah dapat dikenali sebagai berikut: (1)

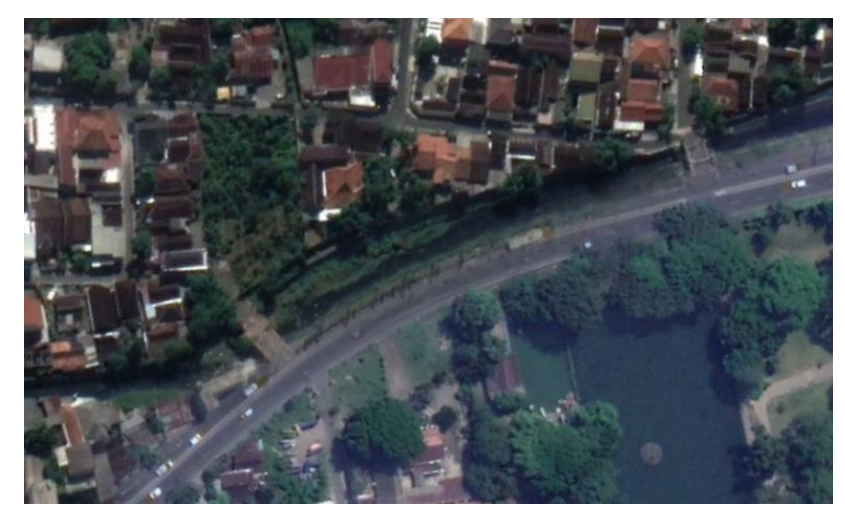

Gambar 1. Daerah Pengambilan Contoh Sampah

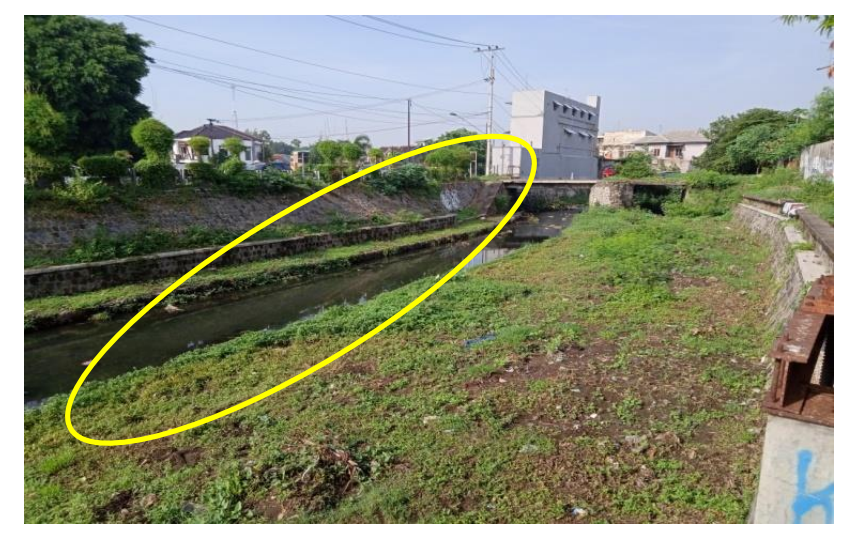

Gambar 2. Kondisi Bantaran Sungai Gajah Putih tingkat produksi sampah, (2) komposisi dan kandungan sampah, (3) kecenderungan perubahannya dari waktu ke waktu.

Karakter sampah tersebut sangat dipengaruhi oleh tingkat pertumbuhan penduduk, pertumbuhan ekonomi dan kemakmuran serta gaya hidup dari masyarakat perkotaan. Oleh karena itu menurut Wibowo dan Djajawinata
(2004), sistem pengelolaan yang direncanakan haruslah mampu mengakomodasi perubahanperubahan dari karakter sampah yang ditimbulkan.

\section{METODE PENELITIAN}

Penelitian dilakukan di sebagian segmen sungai Gajah Putih seperti foto pada gambar 1. Yang berlokasi di wilayah kelurahan Sumber kecamatan Banjarsari Surakarta. Alasan pengambilan segmen tersebut sebagai lokasi penelitian karena pada lokasi tersebut mempunyai potensi terbentuknya sedimentasi yang bercampur dengan sampah. Satu sisi sungai merupakan kawasan tempat tinggal. Sedangkan sisi lainnya jl. Ahmad Yani yang menghubungkan daerah bundaran Manahan dengan terminal bus Tirtonadi.

Gambar 2. adalah foto kondisi bantaran sungai Gajah Putih yang dijadikan lokasi penelitian. Sedimen tersebut terdiri dari tanah yang sudah bercampur dengan sampah.

Pengambilan contoh dilakukan setiap satu minggu, selama empat kali, sehingga secara keseluruhan dibutuhkan waktu satu bulan. Sedangkan urutan dan detail pengukuran akan dijelaskan pada keterangan selanjutnya.

\section{A. DATA YANG DIBUTUHKAN DALAM PENELITIAN}

1. Karakteristik sampah di bantaran sungai Gajah Putih.

2. Karakteristik sampah kawasan rumah tinggal di tepi sungai Gajah Putih. 


\section{B. PERALATAN DAN PERLENGKAPAN}

1. Alat pengambil contoh berupa kantong plastik dengan volume 40 liter.

2. Alat pengukur volume contoh berupa kotak berukuran $20 \mathrm{~cm}$ x $20 \mathrm{~cm}$ x $100 \mathrm{~cm}$, yang dilengkapi dengan skala tinggi.

3. Timbangan (0-5) kg dan (0-100) kg.

4. Alat pengukur, volume contoh berupa bak berukuran $(1,0 \mathrm{~m} \times 0,5 \mathrm{~m} \times 1,0 \mathrm{~m})$ yang dilengkapi dengan skala tinggi.

5. Perlengkapan berupa alat pemindah (sekop) dan sarung tangan.

\section{METODE PENGAMBILAN DAN PENGUKURAN CONTOH}

1. Menentukan lokasi pengambilan sampah

Pengambilan contoh sampah dilakukan di dua sisi. Sisi perumahan dengan mengumpulkan semua sampah yang dihasilkan dari kotak sampah perumahan sampai sejumlah $100 \mathrm{~kg}$. Sisi bantaran dengan mengambil contoh sampah di satu titik bantaran sungai sampai sejumlah $100 \mathrm{~kg}$.

2. Menentukan periode waktu pengambilan contoh sampah

Pengambilan contoh dilakukan satu minggu

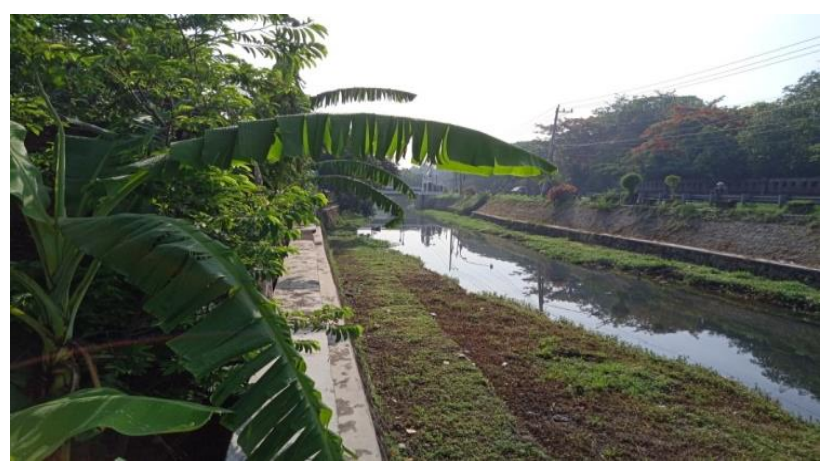

Gambar 3. Bantaran Terhubung Langsung dengan Jalan dan Perumahan sekali untuk sisi perumahan dan bantaran sungai secara bersamaan.

\section{MENENTUKAN JUMLAH TENAGA PELAKSANA}

Untuk tenaga pengumpul contoh tanah menggunakan enam tenaga manusia. Tiga untuk sisi perumahan dan tiga untuk sisi bantaran.

\section{E. MENYIAPKAN PERALATAN}

F. MELAKUKAN PENGAMBILAN DAN PENGUKURAN CONTOH TIMBUNAN SAMPAH

a. Menyiapkan kantong plastik yang sudah diberi kode.

b. Mencatat jumlah unit masing-masing timbulan sampah.

c. Mengumpulkan kantong plastik yang sudah terisi sampah.

d. Mengangkut seluruh kantong plastik ke tempat pengukuran.

e. Menimbang kotak pengukur.

f. Menuang secara bergilir contoh tersebut ke kotak pengukur 40 liter.

g. Menghentak 3 kali kotak contoh .

h. Mengukur dan mencatat volume sampah (Vs).

i. Menimbang dan mencatat berat sampah (Bs).

j. Menimbang bak pengukur 500 liter.

k. Mencampur seluruh contoh dari setiap lokasi kedalam bak 500 liter.

1. Mengukur dan mencatat berat sampah.

m. Menimbang dan mencatat berat sampah.

n. Memilah contoh berdasarkan komponen 


\section{komposisi sampah.}

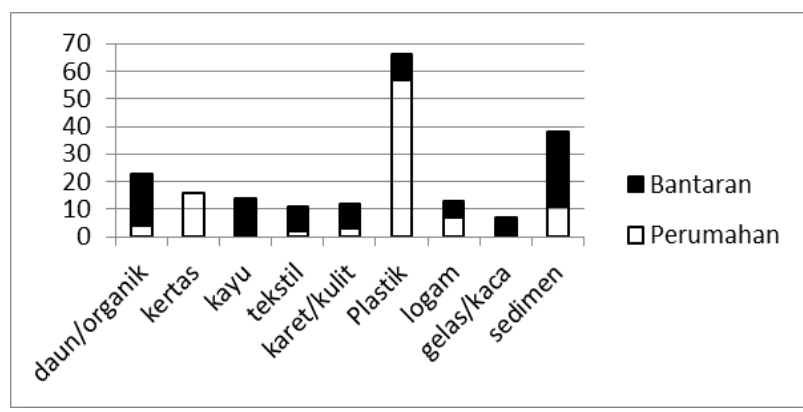

Gambar 6. Perbandingan Karakteristik Sampah Perumahan dan Bantaran Minggu Ketiga

Tabel 1.

Berat Berdasarkan Jenis Sampah Perumahan

\begin{tabular}{cccccc}
\hline \hline & & \multicolumn{4}{c}{ Berat Sampah (kg) } \\
\cline { 3 - 6 } No & \multirow{4}{*}{ Jenis } & M1 & M2 & M3 & M4 \\
\cline { 3 - 6 } & & 5 & 8 & 4 & 7 \\
& & 17 & 21 & 16 & 24 \\
\hline 1 & Daun / Organik & Kertas & 0 & 0 & 0 \\
2 & Kayu & 0 & 3 & 2 & 0 \\
3 & Tekstil & 14 & 5 & 3 & 7 \\
4 & Karet / Kulit & 46 & 49 & 57 & 46 \\
5 & Plastik & 8 & 5 & 7 & 7 \\
6 & Logam & 0 & 0 & 0 & 1 \\
7 & Gelas / Kaca & 10 & 9 & 11 & 8 \\
8 & Sedimen & \multicolumn{4}{|c}{} \\
9 &
\end{tabular}

Tabel 2.

Berat Berdasarkan Jenis Sampah Bantaran

\begin{tabular}{cccccc}
\hline \hline & & \multicolumn{4}{c}{ Berat Sampah (kg) } \\
\cline { 3 - 6 } No & Jenis & \multicolumn{4}{c}{ Minggu } \\
\cline { 3 - 6 } & & M1 & M2 & M3 & M4 \\
\hline \hline 1 & Daun / Organik & 18 & 20 & 19 & 22 \\
2 & Kertas & 0 & 1 & 0 & 1 \\
3 & Kayu & 15 & 12 & 14 & 14 \\
4 & Tekstil & 12 & 11 & 9 & 8 \\
5 & Karet / Kulit & 10 & 7 & 9 & 7 \\
6 & Plastik & 12 & 6 & 9 & 7 \\
7 & Logam & 3 & 4 & 6 & 6 \\
8 & Gelas / Kaca & 5 & 5 & 7 & 6 \\
9 & Sedimen & 25 & 34 & 27 & 29 \\
\hline \hline
\end{tabular}

o. Menimbang dan mencatat berat sampah.

p. Menghitung komponen komposisi sampah.

\section{HASIL DAN PEMBAHASAN}

Karakteristik sampah perumahan tepi sungai Gajah Putih dapat dilihat seperti pada Tabel 1 dan Tabel 2 berikut ini.

Dari Gambar 4, dapat kita ketahui pola sebaran

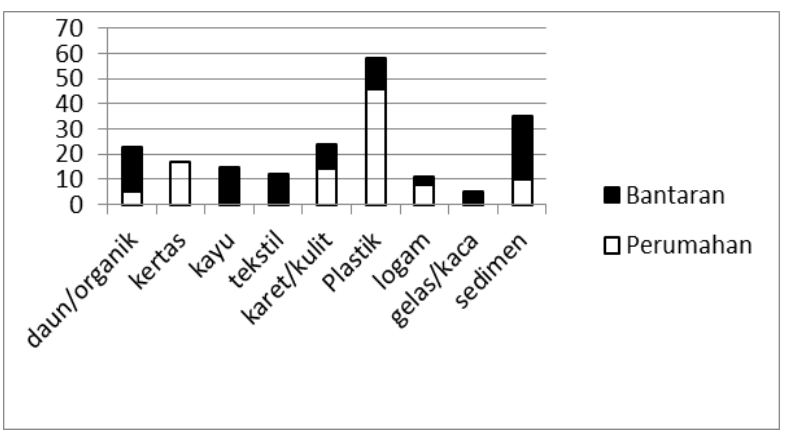

Gambar 4. Perbandingan Karakteristik Sampah Perumahan dan Bantaran Minggu Kesatu

karakteristik sampah yang berasal dari perumahan cenderung berbeda dengan karakteristik sampah yang berada di bantaran sungai Gajah Putih. Sampah dari perumahan didominasi sampah plastik, kertas dan karet. Sedangkan sampah di bantaran sungai didominasi jenis sampah organik, tekstil, dan sedimen.

Gambar 5 menunjukkan pola yang hampir sama dengan Gambar 4. Sebaran karakteristik sampah dari perumahan mempunyai kecenderungan yang berbeda dengan sampah yang berada di bantaran sungai. Adanya kesamaan karakteristik sampah di bantaran dengan sampah

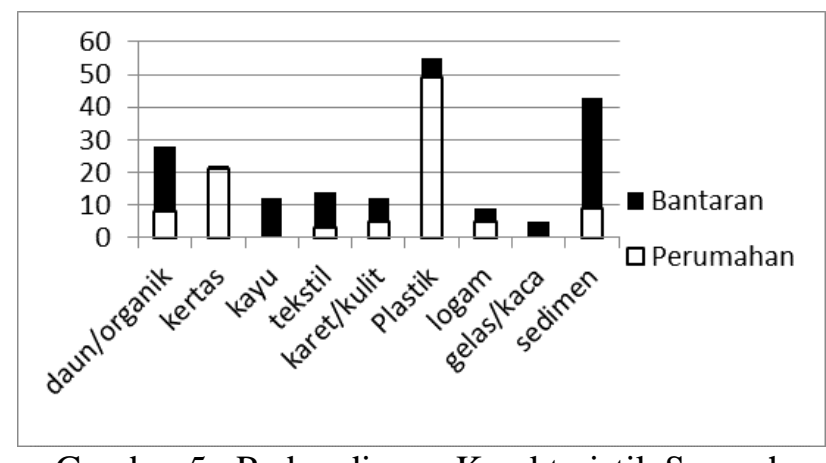

Gambar 5. Perbandingan Karakteristik Sampah Perumahan dan Bantaran Minggu Kedua di perumahan dikarenakan sifat sampah yang mudah terbawa angin. Karakteristik sampah tersebut juga termasuk jenis sampah yang umum terbuang.

Pengamatan perbandingan sampah pada minggu ketiga (Gambar 6) masih menunjukkan 
kecenderungan yang sama. Kecenderungan yang berbeda antara sampah perumahan dengan sampah yang berada di bantaran sungai Gajah Putih. Sampah dari perumahan didominasi jenis sampah plastik dan kertas. Sedang sampah di bantaran sungai didominasi jenis sampah organik, kaca, dan sedimen.

Pada Gambar 7 menggambarkan pola kecenderungan yang masih sama dengan diagram yang lain. Pola sebaran karakteristik sampah mempunyai kecenderungan yang berbeda antara sampah perumahan dengan sampah yang berada di bantaran sungai Gajah Putih.

Dari Gambar 4 - Gambar 7 tersebut diatas dapat kita ketahui adanya kecenderungan yang berbeda terkait jumlah masing-masing jenis sampah. Antara jenis sampah dari perumahan dengan jenis sampah yang berada di bantaran sungai.

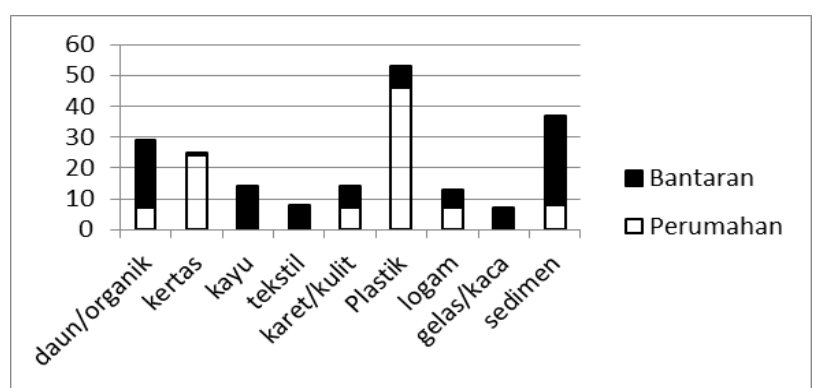

Gambar 7. Perbandingan Karakteristik Sampah Perumahan dan Bantaran Minggu Keempat

\section{KESIMPULAN/RINGKASAN}

1. Sampah yang berada di bantaran sungai Gajah Putih sebagian besar bukan bersumber dari perumahan sekitar sungai Gajah Putih.
2. Sampah yang berada di bantaran sungai Gajah Putih sebagian besar berasal dari sampah yang terbawa aliran sungai sebelum bantaran sungai lokasi pengamatan.

3. Diperlukan pengelolaan sampah yang lebih baik untuk mengantisipasi hal tersebut.

4. Diperlukan penelitian lanjutan guna mengetahui sumber timbulan sampah di bantaran sungai Gajah Putih Surakarta.

\section{DAFTAR PUSTAKA}

Standar Nasional Indonesia Nomor SNI-193964-1994 tentang Metode Pengambilan dan Pengukuran Contoh Timbulan dan Komposisi Sampah Perkotaan, Badan Standar Nasional (BSN)

Standar Nasional Indonesia Nomor SNI-193983-1995 tentang Spesifikasi Timbulan Sampah Untuk Kota Kecil dan Sedang di Indonesia, Badan Standar Nasional (BSN)

Sudradjat R. 2006. Mengelola sampah Kota : Solusi Mengatasi Masalah Sampah Kota dengan Manajemen Terpadu dan Mengolahnya Menjadi Energi Listrik dan Kompos. Penebar Swadaya, Jakarta.

Syafrudin dan Priyambada I.B., 2001. Pengelolaan Limbah Padat. Diktat Kuliah Program Studi Teknik Lingkungan, Fakultas Teknik Undip, Semarang.

Syafrudin, 2004. Pengelolaan Sampah Berbasis Masyarakat. Prosiding Diskusi Interaktif Pengelolaan Sampah Perkotaan Secara Terpadu, Program Magister Ilmu Lingkungan Undip, Semarang.

Chandra, Budiman. 2006. Pengantar Kesehatan Lingkungan. Jakarta : Buku Kedokteran EGC.

Slamet, Juli Soemirat, 2002. Kesehatan Lingkungan. Gadjah Mada University Press, Yogyakarta. 